10. Pisma Janowe (R.A. Culpepper i M.J.J. Menken).

11. Paweł i diaspora żydowska (J.M.G. Barclay i F. Siegert).

12. Korespondencja do Tesaloniczan (J. Beutler i K.P. Donfried).

13. Apokaliptyka w Nowym Testamencie (C.H. Giblin i J.-W. Taeger).

14. Wspólnoty chrześcijańskie i judaizm (G. Rochais i M. Quesnel).

15. Krytyka tekstualna (D.C. Parker).

16. Etyka Nowego Testamentu (R.B. Hays i W. Schrage).

17. Hermeneutyka i tekst biblijny (J.W. Voelz i B.C. Lategan). korný).

18. Treść i problemy nowotestamentalnej teologii $(\mathrm{H}$. Hübner i P. Po-

Ekumeniczne modlitwy poranne były prowadzone kolejno przez husytę (Z. Sázava), katolika (J. Swetnam SI) i protestanta reformowanego (M. Carrez).

Miłe wrażenie na członkach zjazdu pozostawiło zwiedzanie Galerii Narodowej na zamku w Hradczanach, koncert w Muzeum Narodowym, na którym wystąpił z recitalem znany czeski pianista $R$. Kvapil, i oficjalne przyjęcie wydane przez Uniwersytet Karola w pięknym, stylowym pałacyku na Wyspie Zofin. Od strony organizacji zjazdu czuwal z dobraną ekipą P. Pokorný, z wydziału teologii protestanckiej, kończący kadencję przewodniczącego SNTS 1994.

Dokonano wyboru przewodniczących SNTS na następne lata i miejsc przyszłych zjazdów. Na rok 1996 przewodniczącym został wybrany G.N. Stanton (Londyn), a na rok 1997 U. Luz (Berno). Zjazd w 1996 r. odbędzie się w Strasburgu (6-9 sierpnia), w 1997 r. w Birmingham (4-8 sierpnia), a na 1998 przewidziano Kopenhagę.

W jubileuszowym zjeździe praskim wzięło udział ok. 300 członków i zaproszonych gości. Z Polski byli obecni członkowie: ks. prof. S. Pisarek (PAT) oraz niżej podpisany,

Kraków

Ks. JERZY CHMIEL

\author{
Ks. Jerzy Chmiel
}

\title{
NAUKI BIBLIJNE A WSPÓடCZESNA SOCJOLOGIA. MIĘDZYNARODOWE SEMINARIUM INTERDYSCYPLINARNE (EMMETTEN 1995)
}

W uroczej miejscowości Szwajcarii centralnej, Emmetten (800 m npm.), położonej nad Jeziorem Czterech Kantonów, Szwajcarskie Towarzystwo Teologiczne urządziło w dniach 14.-17. września 1995 r. międzynarodowe seminarium interdyscyplinarne „Teologia chrześcijańska a współczesna socjologia". 
Czytelnika RBL zainteresuje przede wszystkim tematyka biblijna obecna na tymże seminarium. W programie były przewidziane dwie grupy robocze (groupes de travail, workshops): 1 . ST i socjologia, 2. NT i socjologia. Ponieważ okazało się, że zbyt mało biblistów zglosiło swój udział w tym spotkaniu, dlatego połączone te dwie grupy w jedną: nauki biblijne a socjologia.

Wygłoszono następujące referaty $\mathrm{z}$ ciekawą i pouczającą dyskusją:

E. Kellenberger, szwajcarski proboszcz zajmujący się biblistyką, opracował ciekawy temat $\mathrm{z}$ bogatą literaturą: „Osadnictwo na wzgórzach izraelskich w okresie żelaza I".

C. Hardmeier, z Uniwersytetu w Greifswald, mówił „O literaturze socjologicznej na temat proroków przy końcu epoki królewskiej”.

J. Chmiel zaproponował mocno dyskutowany temat " "Socjofonia" na przykładzie święta Szawuot - Pentecostes".

I wreszcie Z. Sázava, z wydziału teologii husyckiej Uniwersytetu Karola w Pradze mówił o „Nowotestamentalnej eschatologii jako normie”.

Uroczo położone centrum konferencyjne Seeblick w Emmetten wpływało stymulująco na dyskusję nad referatami i choć nie było wielu uczestników, to jednak zwrócono uwagę na potrzebę uwzględniania aspektów socjologicznych przy interpretacji tekstów biblijnych. Warto przy okazji przypomnieć, że Dokument Papieskiej Komisji Biblijnej o interpretacji Pisma świętego $\mathbf{w}$ Kościele $\mathrm{z} 1993 \mathrm{r}$. podkreśla rolę socjologicznego podejścia (approche) do Biblii (por. I D 1). Jakkolwiek trzeba pamiętać o pewnym ryzyku, na jakie narażają się egzegeci, będący zwolennikami socjologicznego podejścia do Biblii, to jednak ten aspekt otwiera przed egzegezą szerokie perspektywy i przynosi wiele korzyści. Wykorzystanie modelów dostarczanych przez różne dyscypliny socjologiczne zapewnia egzegezie biblijnej i w ogóle interpretacji Biblii - cenną możliwość ciaggłego odnawiania się, pod warunkiem, że nie będzie się naginać tekstu biblijnego do stampowych modeli socjologicznych.

Mam wrażenie, że takie niestampowe modele socjologiczne $w$ odniesieniu do analizy tekstu Biblii zostały zaproponowane na międzynarodowym seminarium interdyscyplinarnym w pięknej scenerii pomiędzy szczytami Pilatus, Bürgenstock, Rigi, niedaleko przelęczy Gottharda, $400 \mathrm{~m}$ nad Jeziorem Czterech Kantonów, gdzie Szwajcarzy wspominają początki swego wolnego kraju.

Ks. JERZY CHMIEL

\section{KOMUNIKAT TOWARZYSTWA BIBLIJNEGO W POLSCE}

Dnia 26 marca 1996 r. odbyło się w siedzibie Towarzystwa Biblijnego w Warszawie posiedzenie Komitetu Krajowego Towarzystwa Biblijnego w Polsce (dalej KKTB), w skład którego wchodzą Kościoły:

Kościół Katolicki, Polski Autokefaliczny Kościół Prawosławny, Kościół Ewangelicko-Augsburski, Kościół Polskokatolicki, Kościół Starokatolicki Mariawitów, Kościół Ewangelicko-Reformowany, Kościół Ewange- 